\section{O paradoxo dos refugiados internos: mendicância e vulnerabilidade dos índios Caingangues no interior do Paraná}

Ravagnani, Milton

Advogado, jornalista, mestre em Direito da Personalidad pelo Centro Universitário Maringá, doutorando em Função Social do Direito Constituional pela Faculdade Autônoma de Direito/São Paulo; docente na Centro Universitário Ingá, Maringá/Pr.e-mail: milton.ravagnani@hotmail.com

\section{Costa, Carlos Eduardo}

Advogado, doutorando em Função Social do Direito Constitucional pela Faculdade Autônoma de Direito/São Paulo, docente da Universidade Federal de Imperatriz do Maranhão ${ }^{2}$, Brasil.

PALAVRAS-CHAVE: refugiados, vulnerabilidade, Direitos Humanos.

Os caingangues (Kaingáng) formam um grupo étnico cuja história remonta a três mil anos em terras brasileiras. Do pouco resgate documental que se tem desse povo, pode-se afirmar que é uma população que sistematicamente se fez valer da migração para fugir de ameaças à sua integridade cultural e acabaram reduzidos a pouco mais de 20.000 indivíduos, distribuídos nos três Estados do Sul do país. Embora formalmente tenham a tutela do Estado, de fato é um grupo de abandonados internos. A consequência dessa incongruência é a ocupação das cidades próximas para a mendicância, caracterizando a supressão de seus direitos humanos, sendo vulnerados e expostos ao abandono do Estado. O Brasil, seguindo a Convenção de 51, desprezou as condições sociais que forçam a exclusão de determinados grupos. Sequer podem contar com o status de refugiados, que lhes concederia uma condição melhor da que atualmente dispõem. A supressão de seu direito a uma identidade cultural própria, representa a mitigação de seus direitos fundamentais que justificaria seu status de refugiado, mas a lei brasileira assim não os contempla. Partindo de uma pesquisa bibliográfica, este estudo utilizou-se da hermenêutica ricoeuriana. Procurou analisar as condições de vulnerabilidade e abandono em que os índios caingangues vivem, correlacionando-as à legislação protetiva que deveria ser inclusiva em relação aos indígenas, entendendo-os como refugiados, mas que os confina em um mundo de miserabilidade. $\mathrm{O}$ humanismo não cumpriu seus ideais no interior do Paraná.

\section{REFERÊNCIAS}

[1] CARNIO, Henrique Garbellini. O Direito e a Política Entre a Obligatio e o Bando. Tese apresentada à banca examinadora da Pontifícia Universidade Católica de São
Paulo como requisito parcial para obtenção do título de Doutor em Direito na área de Filosofia do Direito e do Estado. São Paulo, 2013.

[2] GOODWIN-GILL, Guy, The Refugee in International Law. Disponível em: http://global.oup.com/booksites/content/9780199207633/reso urces/annexe2. Visitado em 19.09.2018.

[3] HOLZHACKER, Vivian. Conceito de Refugiado no Direito Internacional, in Refugiados Ambientais. Editora da Universidade Federal de Roraima, Boa Vista, 2018.

[4] LAROQUE, Luis F.S; DA SILVA, Juciane B. Sehn. A História dos Kaingang da Terra Indígena Linha Glória, Estrela, Rio Grande do Sul, Brasil: Sentidos de Sua (re)Territorialidade. In: Soc. \& Nat., Uberlândia, ano 24 n. 3, 435-448, set/dez. 2012.

[5] TOMMASINO, Kimiye. A história dos Kaingáng na Bacia do Tibagi: uma sociedade Jê Meridional em movimento. Tese de doutoramento apresentada ao Departamento de Antropologia da Faculdade de Filosofia, Letras e Ciências Humanas da Universidade de São Paulo: São Paulo, 1995. 